\title{
Biomaterials
}

Biomaterials 26 (2005) 3953-3960

www.elsevier.com/locate/biomaterials

\section{The role of muscle-derived stem cells in bone tissue engineering}

\author{
Jui-Sheng Sun ${ }^{\mathrm{a}, \mathrm{b}}$, Steven Yueh-Hsiu Wu ${ }^{\mathrm{c}}$, Feng-Huei Lin ${ }^{\mathrm{c}, *}$ \\ ${ }^{a}$ Department of Orthopedic Surgery, Taipei City United Hospital, Taipei, Taiwan, ROC \\ ${ }^{\mathrm{b}}$ Institute of Rehabilitation Science and Technology, National Yang-Ming University, No. 155, Sec. 2, Linong St., Beitou District, \\ Taipei 11221, Taiwan, ROC \\ ${ }^{\mathrm{c}}$ Graduate Institute of Biomedical Engineering, National Taiwan University, No. 1, Jen-Ai Road, Taipei, Taiwan, ROC
}

Received 3 August 2004; accepted 20 October 2004

Available online 25 November 2004

\begin{abstract}
The formation of bone and repair of bone defect requires a source of pluripotential mesenchymal stem cells. However, the capacity of the human body to generate bone components is limited. In this report, we show that the highly purified myogenic cells by the preplate technique have the capacity to differentiate into osteogenic lineage in vitro.

The recombinant human bone morphogenic protein (rh-BMP-2) was immobilized on the molded gelatin composite. Primary muscle cells were isolated from newborn Wistar-rats calf muscle. The cells were then preplated in collagen-coated flasks. After six serial platings, the culture was enriched with small, round cells [pp6]. The effects of immobilized rhBMP-2 on the gelatin scaffold were evaluated by the analysis of alkaline phosphatase (ALP) and osteocalcin in culture medium after seedings of muscle-derived cells [pp6].

The results showed that the cells isolated from pp6 slow adhering cells possessed round mononuclear phenotype, marked ALP stain and matrix mineralization. The synthesis and secretion of ALP from pp6 muscle-derived cells were persistent higher than that of pp1-pp5 groups. The efficacy of rhBMP-2 immobilization on the gelatin scaffolds as manifested as the synthesis and secretion of ALP and osteocalcin from muscle-derived cells was always significantly higher than that of the control samples.

In summary, our results suggest that the muscle-derived pp6 cells were capable of inducing and participating in bone formation. These results suggest that muscle tissue is a valuable resource for osteoprogenitor cells to be used in clinical practice to improve bone healing.
\end{abstract}

(C) 2004 Elsevier Ltd. All rights reserved.

Keywords: Muscle-derived cells; Gelatin; Bone morphogenetic protein 2; Osteocalcin; Bone tissue engineering

\section{Introduction}

It has been established that mesenchymal stem cells derived from bone marrow [1,2] and other connective tissues [3-5] have the potential to differentiate into different lineage upon changes in external stimuli. Skeletal muscle tissue has been extensively investigated as a potential source for isolation of pluripotent stem cells [6-10]. In particular, a myogenic cell line from

\footnotetext{
${ }^{*}$ Corresponding author. Tel.: 886223123456x1149; fax: 886223912641.

E-mail addresses: jssun@ym.edu.tw,drjssun@rst.ym.edu.tw (J.-S. Sun), double@ha.mc.ntu.edu.tw (F.-H. Lin).
}

mouse skeletal muscle has been shown to differentiate into osteoblastic lineage in vitro upon stimulation with bone morphogenetic protein [6]. This means that at least one subpopulation of cells within skeletal muscle can differentiate into multiple lineages.

A recent report has suggested that only a discrete minority of myoblasts can survive after implantation and thus may represent a population of myogenic stem cells [11]. This results suggest that satellite cells are highly heterogeneous in nature. Our attempt is to investigate whether highly purified muscle-derived cells (by preplate technique) will express markers of stem cells and differentiate into osteogenic lineage. In this report, we show that the highly purified muscle-derived cells 
express behaviors indicative of stem cells. More importantly, when the cells implanted on a porous gelatin biodegradable scaffold with rhBMP-2 immobilized on the surface have the capacity to differentiate into osteogenic lineage in vitro. Thus, our results suggest that a subpopulation of muscle-derived cells can differentiate into osteogenic lineages and have a potential in bone tissue engineering.

\section{Materials and methods}

\subsection{Preparation of gelatin composites scaffold}

The gelatin powder (G-2500; Sigma, St. Louis, MO, USA) was extracted and purified from the porcine skin with the average molecular weight of about $60,000-100,000 \mathrm{Da}$. In the present study, the gelatin powder was weighted and dissolved in the deionized water until a homogeneous $10.0 \%$ gelatin solution was attained. The dissolution was kept at $65^{\circ} \mathrm{C}$ using a water bath. A $0.1 \%$ glutaraldehyde (Sigma, St. Louis, MO, USA) solution was added to the gelatin solution for matrix cross-linking at $35^{\circ} \mathrm{C}$. After the matrix was cross-linked, the cylinder composite was molded and dried in $-4{ }^{\circ} \mathrm{C}$, then concentrated in $-20^{\circ} \mathrm{C}$ with vacuum evaporation for $24-48 \mathrm{~h}$. The molded gelatin composite was further cross-linked with $0.1 \%$ glutaraldehyde solution for another $8 \mathrm{~h}$, thoroughly washed with PBS solution, soaking with $0.1 \mathrm{M}$ glycine (G-8898; Sigma, St. Louis, MO, USA) solution for $24 \mathrm{~h}$ and sterilized with $75 \%$ ethyl alcohol for $2 \mathrm{~h}$, then the residual ethanol were removed with PBS solution. The sterile cross-linked gelatin composites were kept sterile for further study.

\subsection{Purified Isolation of muscle-derived cells}

Primary muscle cells were isolated from newborn Wistar-rats calf muscle using a technique previously described [12]. The cells were then preplated in collagencoated flasks [12]. After $1 \mathrm{~h}$, the supernatant was withdrawn from the flask and replated in a fresh collagen-coated flask. The cells that adhered rapidly within this 1-h incubation were mostly fibroblasts [12]. The serial replating of the supernatant was repeated when $30-40 \%$ of the cells had adhered to each flask. After six serial platings ( $24 \mathrm{~h}$ for each following plating), the culture was enriched with small, round cells [pp6]. The cells of pp1-pp6 were seeded in 12-well plates at a density of 50-60 cells/well. The cultures were kept in a humidified atmosphere with $5 \% \mathrm{CO}_{2}$ and $95 \%$ air at $37^{\circ} \mathrm{C}$. The culture media used were $\alpha$-MEM supplemented with penicillin $(100 \mathrm{U} / \mathrm{ml})$, streptomycin $(100 \mathrm{mg} / \mathrm{ml})$, and $20 \% \mathrm{FBS}$, ascorbic acid $(50 \mu \mathrm{g} / \mathrm{ml})$, and $\beta$-glycerophosphoric acid disodium salt $(5 \mathrm{~mm})$; fresh medium was replaced every 3 days. The cells of pp1, pp2 $\ldots$ and pp6 were analyzed at 7, 14, 21, 28 days of culture for alkaline phosphatase (ALP) and vonKossa stain as described below. This study received prior approval of the National Taiwan University Medical College's Animal Research Committee.

\subsection{ALP staining}

After fixing the cells, the dishes were incubated for $30 \mathrm{~min}$ in Tris Buffer $(0.2 \mathrm{M}, \mathrm{pH} 8.3)$ with AS-MX phosphate (Sigma, St. Louis, MO, USA) as a substrate and Fast Blue (Sigma, St. Louis, MO, USA) as a stain. The ALP positive cells stained blue/purple. For each experiment, a minimum of three dishes was counted and the experiments were repeated three times.

\subsection{The von-Kossa staining on mineralized nodules formation}

Mineralization of the nodules in the cultures was assessed by using von-Kossa stain. The matrix was washed with PBS, and the cultures were treated with 5\% silver nitrate solution $100 \mu \mathrm{l} /$ well in the dark at $37^{\circ} \mathrm{C}$ for $30 \mathrm{~min}$. The excess silver nitrate solution was then completely washed away using double-distilled $\mathrm{H}_{2} \mathrm{O}$ and the culture plate was exposed to sodium carbonate/ formaldehyde solution for few minutes to develop color. Mineralized and unmineralized nodules could be distinguished separately: mineralized nodules by their von Kossa-positive staining (dark brown center and light brown peripheral area), and unmineralized nodules by their surface layer of cuboidal cells, light brown staining, and three-dimensional structure. For each experiment, a minimum of three dishes was counted and the experiments were repeated three times.

\subsection{Preparation of rhBMP-2 immobilized gelatin composites}

Gelatin is the denatured collagen fragment with a serial of amino acids sequence. It provides many functional groups, $-\mathrm{COOH},-\mathrm{NH}_{2}$, and $-\mathrm{OH}$, those can be used to cross-link with the other proteins [13]. We use 1-ethyl-3-(3-dimethylaminopropyl) carbodiimide (EDAC; Sigma Co., St. Louis, MO, USA) as the cross linker to link the functional group $\left(-\mathrm{NH}_{2}\right)$ of recombinant human bone morphogenic protein (rh-BMP-2; R\&D System 355-BM, Minneapolis, MN, USA) and gelatin by $-\mathrm{COOH}$ group. Briefly, $0.5 \times 0.5 \times 0.5 \mathrm{~mm}^{3}$ cross-linked gelatin scaffold was soaked in $1.0 \mathrm{ml}$ of $0.2 \%$ EDAC solution at a temperature of $4{ }^{\circ} \mathrm{C}$. After $3 \mathrm{~min}$, the excessive EDAC was removed and then the scaffold was further soaked with $200 \mathrm{ng} / \mathrm{ml} \mathrm{rh}-\mathrm{BMP}-2$ for $2 \mathrm{~min}$. The rhBMP-2 immobilized gelatin composites were then collected for further analysis. 
The percentage of rhBMP-2 release from gelatin scaffold immobilization was evaluated by BMP-2 immunoassay quantitative EIA kit (R\&D SystemMinneapolis, MN, USA). The non-immobilized rhBMP-2 left in the soaking solution was analyzed by ELISA methods. Briefly, $50 \mu 1$ of standard rhBMP-2 or sample was added per well. The tested samples were incubated on the benchtop for $18 \mathrm{~h}$ at room temperature. Then $100 \mu \mathrm{l}$ of Assay Diluent RD-19 Reagent were added to each well and incubated for $2 \mathrm{~h}$ at room temperature, washed and then $200 \mu \mathrm{l}$ BMP-2 Conjugate was added and incubated for another $2 \mathrm{~h}$. Two hundred microliters of substrate solution was added for $30 \mathrm{~min}$ and the reaction was stopped and read by a Microelisa reader (Emax Science Corp., Sunnyvale, CA, USA) at $450 \mathrm{~nm}$.

\subsection{Evaluation of the efficacy of rhBMP-2 immobilized gelatin composites}

Initially, the cells of pp6 were seeded in 12-well plates at a density of 50-60 cells/well. After 2-3 weeks culture, the cells reached confluence; they were harvested and seeded into rhBMP-2 immobilized gelatin scaffold. The scaffolds were kept in a humidified atmosphere with $5 \% \mathrm{CO}_{2}$ and $95 \%$ air at $37^{\circ} \mathrm{C}$ for $24 \mathrm{~h}$, and then transferred to a custom-made bioreactor which was equipped with a self-exchange system for culture medium and air. The culture media used were $\alpha$ MEM supplemented with penicillin $(100 \mathrm{U} / \mathrm{ml})$, streptomycin $(100 \mathrm{mg} / \mathrm{ml}), 10 \%$ FBS, ascorbic acid $(50 \mathrm{mg} / \mathrm{ml})$, and $\beta$-glycerophosphoric acid disodium salt $(5 \mathrm{~mm})$; fresh medium was replaced every 3 days. For the control group, the gelatin scaffold without rhBMP-2 immobilization was treated similar to that of the study sample, except that no rhBMP-2 was added during the preparation.

Half of the culture media were obtained at $7 \mathrm{th}, 14 \mathrm{th}$, 21 st, 28th day. The media were removed from wells, divided into section of $500 \mu \mathrm{l}$ with eppendorf, and then deeply frozen in $-80{ }^{\circ} \mathrm{C}$ for further analysis. An equal amount of medium was added after each sampling of tested medium.

\subsection{Analysis of ALP in culture medium}

ALP activity released from the cells into the medium was measured with a commercially available assay kit (procedure no. ALP-10, Sigma Co., St. Louis, MO, USA). Briefly, an aliquot $(20 \mu \mathrm{l})$ from the media was mixed with $1 \mathrm{ml}$ ALP reagent. The absorbance at $405 \mathrm{~nm}$ caused by $p$-nitrophenol production was followed for $5 \mathrm{~min}$ at $30^{\circ} \mathrm{C}$. The change in rate of absorbance was directly proportional to ALP activity.

\subsection{Analysis of osteocalcin in culture medium}

The production of osteocalcin in culture medium was analyzed by ELISA methods (Rat Gla-Oc Competitive EIA kit (Takara, MK121, Takara Bio. Inc., Otsu, Shiga, Japan)). Briefly, $100 \mu 1$ of standard or sample was added per well. The tested samples were incubated on the benchtop for $1 \mathrm{~h}$ at room temperature, then washed with PBS solution, and $100 \mu 1$ of substrate solution was added to and incubated for $1 \mathrm{~h}$ at room temperature. The reaction was stopped and read by a Microelisa reader (Emax Science Corp., Sunnyvale, CA, USA) at $405 \mathrm{~nm}$ after $20 \mathrm{~min}$ incubation.

\subsection{Statistical analysis}

The differences between various tested conditions were evaluated by the paired $t$-test. The level of statistical significance is defined as $P<0.05$.

\section{Results}

\subsection{Characterization of purified muscle-derived cells}

Cells isolated from pp1 primary culture contain most of fibroblasts which proliferated rapidly and became confluence at 1 week of culture. Cells isolated from pp2 and pp 3 primary culture contain $30-40 \%$ non-myogenic fibroblasts-like cells. Cells isolated from pp4 and pp5 primary culture fused and became myotubes at the end of 1 st week of culture which means most myogenic cells existed in this part of isolation. The cells isolated from pp6 slow adhering cells possessed round mononuclear phenotype, which meant that most cells were not myogenic (Fig. 1).

\subsection{In vitro differentiation of clonal pp6 cells into osteogenic lineage}

\subsubsection{ALP stain and the von-Kossa staining}

In the pp6 sample, the ALP stain appeared at the first three weeks culture. The formation of ALP stain attained its maximal manifestation at the 3rd week's culture; then decreased in intensity at the 4th week's culture (Fig. 2).

The first sign of matrix mineralization was observed grossly as sparse brown crystals in the matrix around the 7 th day. Mineralization gradually increased during the 7-28th days, and attained a significant degree at the 21st day's culture (Fig. 3). When pp6 cells cultured with the differentiation medium, the progress of matrix mineralization seemed diffusely spread; and at the end of 28 days' culture, marked mineralization nodules were observed in the tested samples (Fig. 3). 

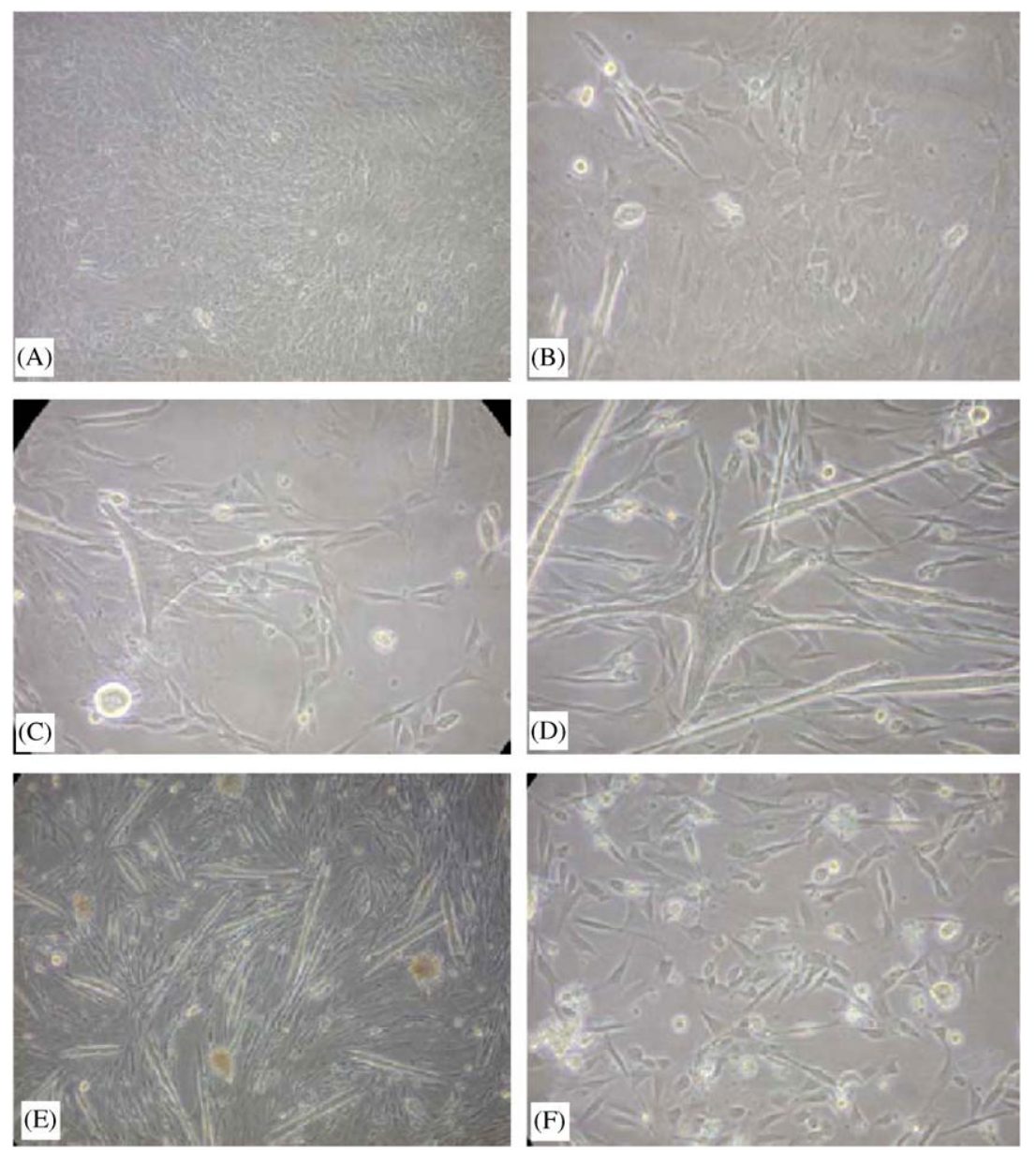

Fig. 1. Morphologic characterization of purified muscle-derived cells: cells isolated from pp1 (A) primary culture contain most of fibroblasts which proliferated rapidly and became confluence at 1 week of culture. Cells isolated from pp2 (B) and pp3 (C) primary culture contain $30-40 \%$ nonmyogenic fibroblasts-like cells. Cells isolated from pp4 (D) and pp5 (E) primary culture fused and became myotubes at the end of 1 st week of culture which means most myogenic cells existed in this part of isolation. The cells isolated from pp6 (F) slow adhering cells possessed round mononuclear phenotype, which meant that most cells were not myogenic. Notes: (A) pp1; (B) pp2; (C) pp3; (D) pp4; (E) pp5; and (F) pp6.

\subsubsection{ALP synthesis and secretion}

During these 4 weeks culture, the synthesis and secretion of ALP from muscle-derived cells were quite persistent for pp2-pp5 groups; while in the pp6 group, the ALP synthesis and secretion attained its maximal at the first week of culture. During the 4 weeks culture, the secretion and synthesis of ALP is persistently higher than that of pp2-pp5 groups $(P<0.005$; Fig. 4$)$.

\section{3. rhBMP-2 release from $r h B M P-2$ immobilized gelatin scaffold}

Our results showed that $90 \%$ of rhBMP- 2 added can be immobilized on the surface of cross-linked gelatin scaffold. Fig. 5 represents the percentage rhBMP-2 released into the soaking solutions. We found that they exhibited higher releasing activity during the first $3 \mathrm{~h}$ of soaking and attained $30 \%$ of total rhbMP- 2 immobilized. The releasing activity tended to be slower and attained $56 \%$ of total rhBMP- 2 immobilized at the 24 th hour of test (Fig. 5).

\subsection{Efficacy of rhBMP-2 immobilized gelatin composites}

\subsubsection{ALP synthesis and secretion}

During these 4 weeks' culture, the synthesis and secretion of ALP from muscle-derived cells slowly increased as the time of culture increased. The synthesis and secretion of ALP from muscle-derived cells were always significantly higher in the rhBMP-2 immobilized composites than that of the control samples $(P<0.05$; Fig. 6).

\subsubsection{Analysis of osteocalcin in culture medium}

During these 4 weeks' culture, the synthesis and secretion of bone Gla-protein (osteocalcin) of the control samples were quite stable; while in the rhBMP2 immobilized group, the synthesis and secretion of osteocalcin from muscle-derived cells increased 

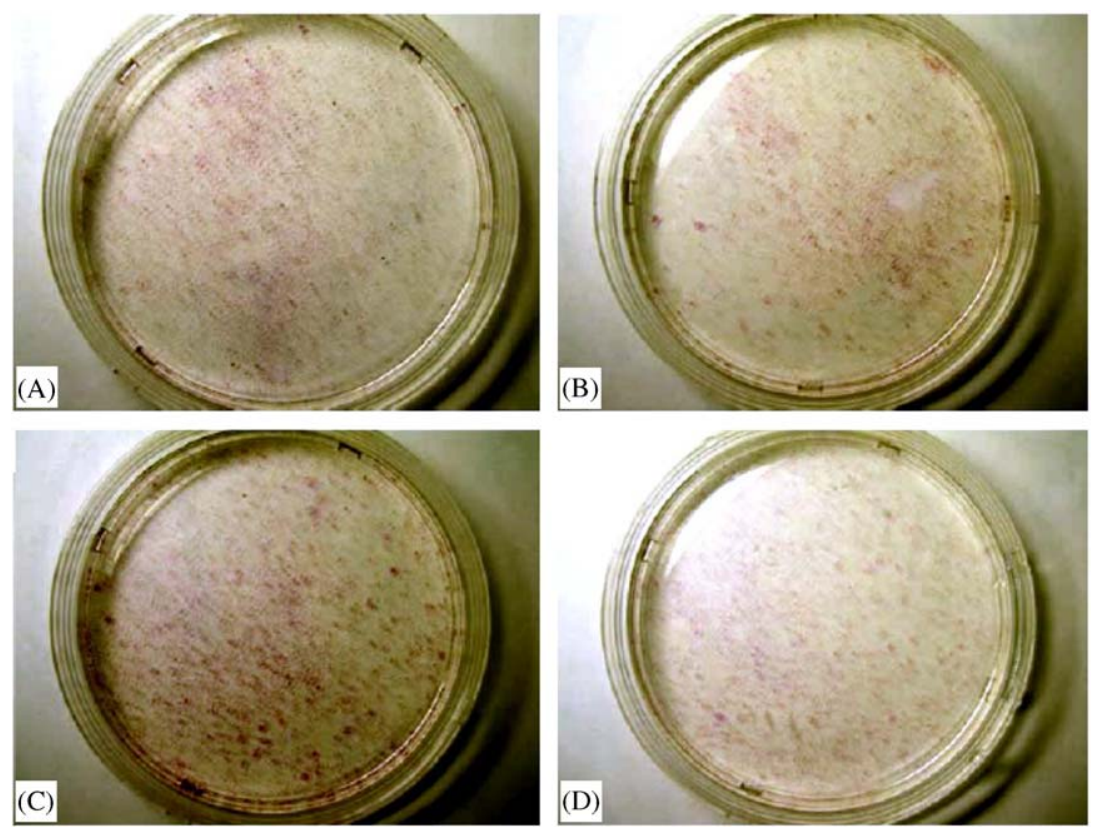

Fig. 2. In vitro differentiation of purified muscle-derived pp6 cells into osteogenic lineage (ALP stain). The ALP stain appeared at the first 3 weeks' culture. At the 3rd week's culture, the formation of ALP stain attained its maximal manifestation, then decreased in intensity at the 4th week's culture. Notes: (A) 1 week; (B) 2 week; (C) 3 week; and (D) 4 week.
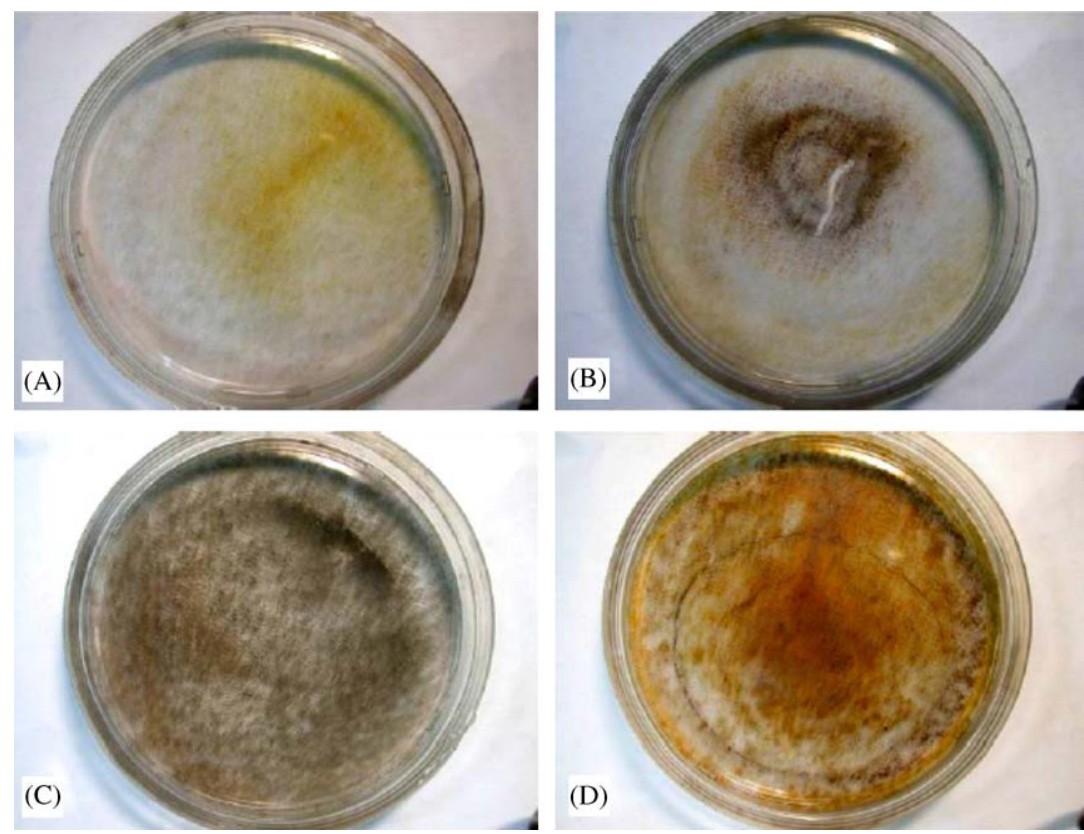

Fig. 3. In vitro differentiation of purified muscle-derived pp6 cells into osteogenic lineage (von-Kossa staining). The first sign of matrix mineralization was observed grossly as sparse brown crystals in the matrix around the 7th day. Mineralization gradually increased during the 7 th-28th days, and attained a significant degree at the 21 st day's culture. When pp6 cells cultured with the differentiation medium, the progress of matrix mineralization seemed diffusely spread, and the end of 28 days' culture, marked mineralization nodules were observed in the tested samples. Notes: (A) 1 week; (B) 2 week; (C) 3 week; and (D) 4 week.

gradually and attained a significant higher level at the 2nd week $(P<0.05$; Fig. 7). At the end of 4 weeks' culture, the secretion of osteocalcin from rhBMP-2 immobilized gelatin composites was 2.26 times of the control samples.

\section{Discussion}

Autogenous bone graft is regarded as the gold standard for bone graft implantation since it can provide three necessary elements for bone regeneration, 


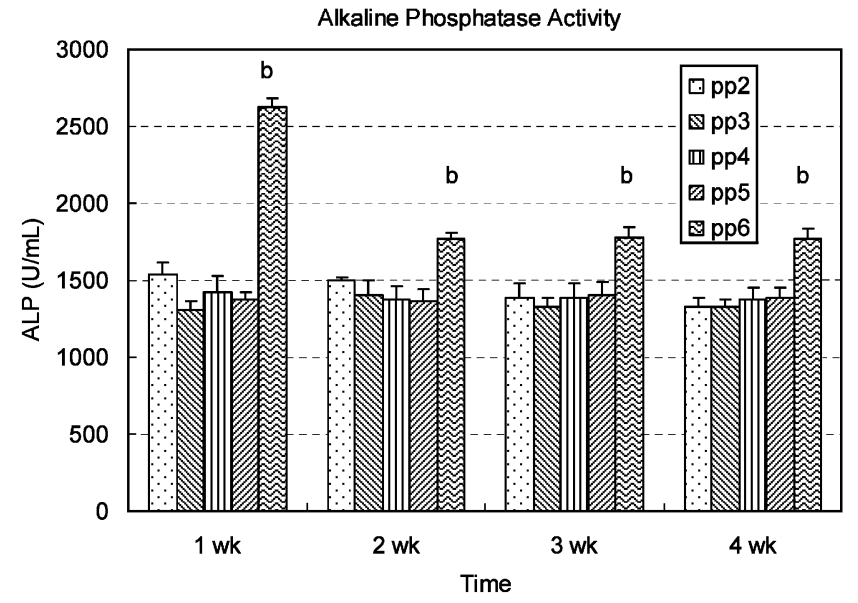

Fig. 4. Synthesis and secretion of ALP by purified muscle-derived cells. During these 4 weeks' culture, the synthesis and secretion of ALP from muscle-derived cells were quite persistent for $\mathrm{pp} 2-\mathrm{pp} 5$ groups; while in the pp6 group, the ALP synthesis and secretion attained its maximal at the first week of culture. During the 4 weeks' culture, the secretion and synthesis of ALP is persistently higher than that of pp2-pp5 groups $(P<0.005)$.

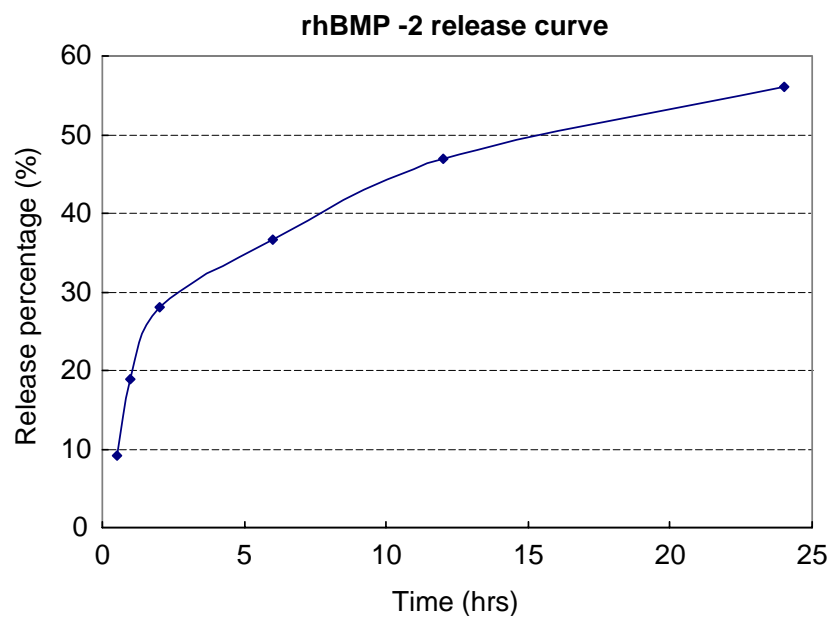

Fig. 5. Releasing activity of rhBMP-2 from gelatin scaffold: $30 \%$ of immobilized rhBMP-2 was released in the first $3 \mathrm{~h}$ of soaking; then releasing activity tended to be slower and attained $56 \%$ of total rhBMP-2 immobilized at 24 h. Notes: (a) $P<0.05$, and (b) $P<0.005$.

i.e. scaffolding for osteoconduction, inductive agents for osteoinduction, and the progenitor cells for osteogenesis. However, the availability of autograft is limited and the procedure to harvest the bone graft is associated with possible donor site morbidity. In this study, our goal is to find an alternative source of osteogenic cells from muscle-derived cells and their possible applications in bone tissue engineering.

We have observed that the preplate technique enriches for a population of muscle-derived cells that express both early myogenic potentials (pp4 and pp5 cells). Our vitro study showed that this population of cells had high incidence of myotubes formation [14,15]. Our results also showed that the muscle derived pp6 cells has slow

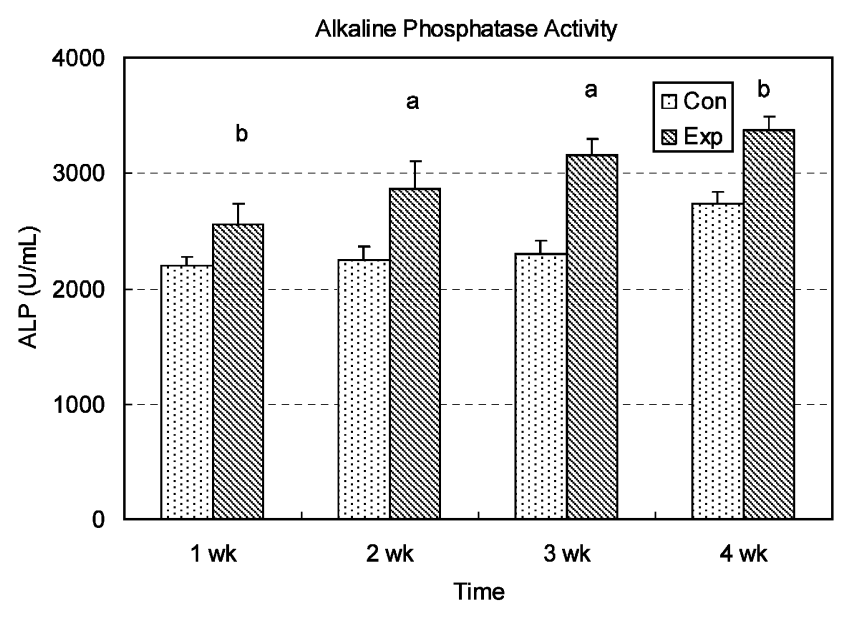

Fig. 6. Effect of rhBMP-2 on osteogenesis of muscle-derived pp6 cells: Synthesis and secretion of ALP. The synthesis and secretion of ALP from muscle-derived cells slowly increased during these 4 weeks' culture. The synthesis and secretion of ALP from muscle-derived pp6 cells were always significantly higher in the rhBMP-2 immobilized composites than that of the control samples. Notes: (a) $P<0.05$, and (b) $P<0.005$.

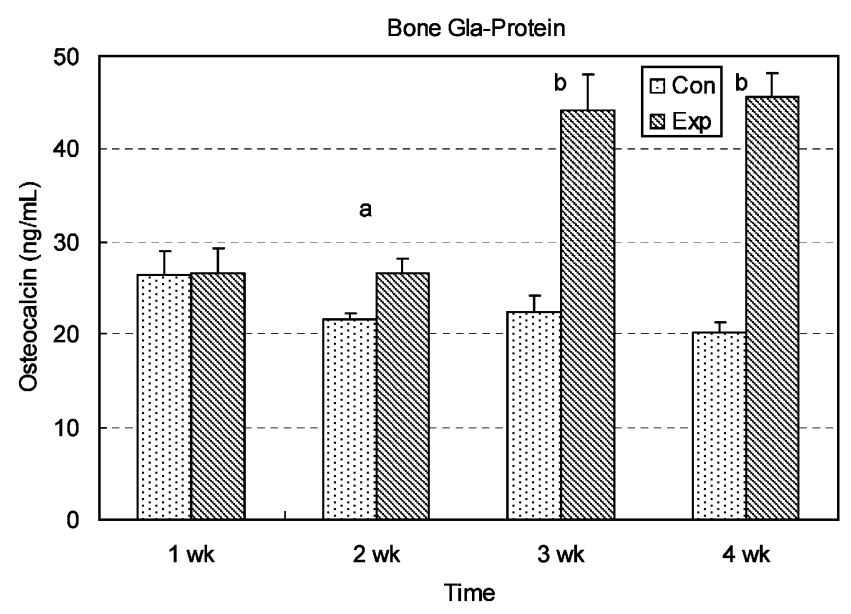

Fig. 7. Effect of rhBMP-2 on osteogenesis of muscle-derived pp6 cells: Synthesis and secretion of osteocalcin: During these 4 weeks' culture, the synthesis and secretion of bone Gla-protein (osteocalcin) of the control samples were quite stable; while in the rhBMP-2 immobilized group, the synthesis and secretion of osteocalcin from muscle-derived pp6 cells increased gradually and attained a significant higher level at the 2 nd week. At the end of 4 weeks' culture, the secretion of osteocalcin from rhBMP-2 immobilized gelatin composites was 2.26 times of the control samples. Notes: (a) $P<0.05$, and (b) $P<0.005$.

adhering ability and also possessed round mononuclear phenotype. In fact, the cells isolated at pp6 in our experiments were highly different from the cells isolated at pp1-pp5 in term of in vitro phenotype expression. Clearly, more studies were required to accurately assess the origin and, more importantly, the functional properties of the pp6 population of muscle-derived cells. As noted in this study, both the ALP stain and matrix mineralization nodules formation appeared after being 
cultured in the differentiation medium for 1 week. Both the ALP staining and mineralization nodules formation gradually increased during the culture period, and marked mineralization nodule formations were observed in the tested samples at the end of 28 days culture. These facts suggested that these highly purified muscle-derived cells (pp6) were able to differentiate into osteogenic lineage in vitro [10]. This suggestion was further supported by the results that the muscle-derived pp6 cells synthesized and secreted higher titer ALP into medium than that of pp2-pp5 cells.

One might expect the direct implantation of progenitor cells to lead to more rapid, uniform, and reliable healing of bone defects. A major challenge to this approach has been the identification of the proper type and source of cells for autologous cell therapy. Several experimental approaches have been utilized to elicit the formation of bone in segmental bone defects and to promote their healing. These approaches have included the implantation of osteoconductive extracellular-matrix scaffolds [16,17] and the implantation of bone morphogenic proteins in various matrices [18-20]. In the current study, we tried to evaluate the ability of rhBMP2 immobilized gelatin composites to elicit their osteogenic capability.

The immobilized rhBMP-2 can be released from gelatin scaffold. Our results showed that $30 \%$ of rhBMP-2 immobilized can be released in the first $3 \mathrm{~h}$ and attained $56 \%$ of total rhBMP-2 immobilized at the 24th hour. When the gelatin scaffolds were immobilized with rhBMP-2, the synthesis and secretion of ALP and osteocalcin from muscle-derived cells were always significantly higher than that of the control samples $(P<0.05)$. Bone Gla-protein (osteocalcin) have been found to have highly restricted patterns of expression in bone, and been reported to occur only exclusively in bone tissue and cells [21]. Assays for osteocalcin are currently used clinically to monitor the levels of bone formation. Increases in osteocalcin levels are presumed to reflect increases in bone formation and bone turnover [21]. From our results, we suggested that the osteogenic ability of the muscle-derived cells can be enhanced by rhBMP-2 released from the gelatin scaffold, and the stimulation with the released BMP-2 can enhance the differentiation of these muscle-derived pp6 cells in osteogenic lineage to consequently improve bone healing.

In summary, our results suggest that the musclederived pp6 cells was capable of inducing and, more importantly, participating in bone formation. It is likely that the transplanted muscle cells are acting as a source of cells that differentiate into osteoblasts and participating in bone formation. These results consolidate that the muscle tissue is a valuable resource for osteoprogenitor cells which can be used in clinical setting to improve bone healing. These new results will shed more light on the functional properties of the muscle-derived stem cells and further support that muscle tissue may become a valuable resource for the isolation of osteoprogenitor cells capable of improving bone healing. Further characterization of these muscle-derived stem cells will open an array of possibilities for advancement of tissue engineering and tissue transplantation techniques.

\section{Conclusions}

The purified muscle-derived cells can differentiate into osteogenic lineages and proceed to mineralization and possible bone tissue formation. This concluded that the the muscle tissue may become a valuable resource for the isolation of osteoprogenitor cells capable of improving bone healing.

\section{References}

[1] Caplan AI. Mesenchymal stem cells. J Orthop Res 1991;9:641-50.

[2] Pittenger MF, MacKay AM, Beck SC, Jaiswal RK, Douglas R, Mosca JD, Moorman MA, Simonetti DW, Craig S, Marshak DR. Multilineage potential of adult human mesenchymal stem cells. Science 1999;284:143-7.

[3] Young HE, Ceballos EM, Smith JC, Mancini ML, Wright RP, Ragan BL, Bushell I, Lucas PA. Pluripotent mesenchymal stem cells reside within avian connective tissue matrices. In Vitro Cell Dev Biol 1993;29A:723-6.

[4] Young HE, Mancini ML, Wright RP, Smith JC, Black AC, Reagan CR, Lucas PA. Mesenchymal stem cells reside within the connective tissues of many organs. Dev Dyn 1995;202:137-44.

[5] Lucas PA, Calcutt AF, Southerland SS, Warejcka D, Young HE. A population of cells resident within embryonic and newborn rat skeletal muscle is capable of differentiating into multiple mesordermal phenotypes. Wound Rep Reg 1995;3:457-68.

[6] Katagiri T, Yamaguchi A, Komaki M, Abe E, Takahashi N, Ikeda T, Rosen V, Wozney JM, Fujisawa-Sehara A, Suda T. Bone morphogenetic protein-2 converts the differentiation pathway of C2C12 myoblasts into the osteoblast lineage. J Cell Biol 1995;127:1755-66.

[7] Cornelison DD, Wold BJ. Single-cell analysis of regulatory gene expression in quiescent and activated mouse skeletal muscle satellite cells. Dev Biol 1997;191:270-83.

[8] Gussoni E, Soneoka Y, Strickland CD, Buzney EA, Khan MK, Flint AF, Kunkel LM, Mulligan RC. Dystrophin expression in the $\mathrm{mdx}$ mouse restored by stem cell transplantation. Nature 1999;401:390-4.

[9] Jackson KA, Mi T, Goodell MA. Hematopoietic potential of stem cells isolated from murine skeletal muscle. Proc Natl Acad Sci USA 1999;96:14482-6.

[10] Bosch P, Musgrave DS, Lee JY, Cummins J, Shuler F, Ghivizzani SC, Evans CH, Robbins PD, Huard J. Osteoprogenitor cells within skeletal muscle. J Orthop Res 2000;18(6):933-44.

[11] Beauchamps JR, Morgan JE, Pagel CN, Partridge TA. Dynamics of myoblast transplantation reveal a discrete minority of precursors with stem cell-like properties as the myogenic source. J Cell Biol 1999;144:1113-22.

[12] Qu-Petersen Z, Deasy B, Jankowski R, Ikezawa M, Cummins J, Pruchnic R, Mytinger J, Cao B, Gates C, Wernig A, Huard J. Identification of a novel population of muscle stem cells in mice: potential for muscle regeneration. J Cell Biol 2002;157:851-64. 
[13] Lin FH, Dong KC, Sun JS, Huang CW. A study on grafting and characterization of HMDI-modified calcium hydrogenphosphate. Biomaterials 2001;20:3179-89.

[14] Lee JY, Qu-Petersen Z, Cao B, Kimura S, Jankowski R, Cummins J, Usas A, Gates C, Robbins P, Wernig A, Huard J. Clonal isolation of muscle-derived cells capable of enhancing muscle regeneration and bone healing. J Cell Biol 2000;150: 1085-99.

[15] Seale P, Asakura A, Michael A. Rudnicki. The potential of muscle stem cells. Dev Cell 2001;1:333-42.

[16] Hollinger JO, Brekke J, Gruskin E, Lee D. Role of bone substitutes. Clin Orthop 1996;324:55-65.

[17] Johnson KD, Frierson KE, Keller TS, Cook C, Scheinberg R, Zerwekh J, Meyers L, Sciadini MF. Porous ceramics as bone graft substitutes in long bone defects: a biomechanical, histological, and radiographic analysis. J Orthop Res 1996;14:351-69.
[18] Mayer M, Hollinger J, Ron E, Wozney J. Maxillary alveolar cleft repair in dogs using recombinant human bone morphogenetic protein-2 and a polymer carrier. Plast Reconstr Surg 1996;98:247-59.

[19] Yasko AW, Lane JM, Fellinger EJ, Rosen V, Wozney JM, Wang EA. The healing of segmental bone defects, induced by recombinant human bone morphogenetic protein (rhBMP-2). A radiographic, histological, and biomechanical study in rats. J Bone Surg 1992;74A:659-70.

[20] Kawasaki K, Aihara M, Honmo J, Sakurai S, Fujimaki Y, Sakamoto K, Fujimaki E, Wozney JM, Yamaguchi A. Effects of recombinant human bone morphogenetic protein-2 on differentiation of cells isolated from human bone, muscle, and skin. Bone 1998;23:223-31.

[21] Young MF. Bone matrix proteins: their function, regulation, and relationship to osteoporosis. Osteoporos Int 2003;14(Suppl. 3):S35-42. 